See discussions, stats, and author profiles for this publication at: https://www.researchgate.net/publication/332038948

\title{
Through The Pyramid: implications of interconnectedness in Africa
}

Article in European Business Review · March 2019

DOI: 10.1108/EBR-01-2018-0006

3 authors, including:

(8) Kerry Chipp

University of Pretoria

25 PUBLICATIONS 97 CITATIONS

SEE PROFILE

Some of the authors of this publication are also working on these related projects:

Respect and the low income consumer: navigating service environments View project

Consumer value journey View project 


\title{
"Through The Pyramid: implications of interconnectedness in Africa"
}

\author{
Kerry Chipp*广, Marcus Carter** and Manoj Chiba** \\ * KTH, Sweden and GIBS, University of Pretoria, South Africa; *GIBS, University of Pretoria, South \\ Africa
}

${ }^{\dagger}$ Author to which correspondence should be addressed

Chippk@gibs.co.za

Gordon Institute of Business Science

P O Box 787602. Sandton, South Africa, 2146

\begin{abstract}
Purpose: Many markets are conceptualized as a stratified low- and middle-income "pyramid" of consumers. Emerging markets are sites of rapid consumer mobility, and thus the middle class there is connected to, and often supports, low-income relatives and employees. Therefore, this paper seeks to establish that African income groups are not insular, but rather interrelated and have strong social ties reinforced with longstanding communal values, such as ubuntu.
\end{abstract}

Design/methodology/approach: Using a between-subjects experimental vignette design, the propensity of the middle class to cover low-income individuals on an insurance product was assessed.

Findings: Income strata are interrelated and can inform value propositions, which is demonstrated in this paper with insurance, where the middle class are willing to include others, depending on their social proximity, on their insurance cover.

Research limitations/implications: The context for this study was personal home insurance, hence, the generalisability of the results is circumscribed. Other more tangible forms of cover, such as medical, funeral or educational insurance, may engender far stronger effects.

Practical implications: Marketers tend to view low- and middle-income consumers as independent. A view of their interrelation will change the design of many products and services, such as a service catered to the poor but targeted at their support networks. An example of such a service is insurance, which is traditionally hard to sell to the poor. A less atomistic approach to income strata could have implications for vicarious consumption, as well as a reconsideration of the disposable income of both groups. 
Originality/value: The pyramid is an interconnected network of social and economic ties.

Paper type: Research paper

Keywords: Low-income, middle income, social networks, cultural embeddedness, insurance, emerging markets, black tax, ubuntu 


\section{Introduction}

Since Prahalad (Prahalad and Hammond, 2002) brought the potential of the world's poor as a market to prominence, a strong research stream has emerged. The term "bottom of the pyramid" (BoP) has entered into our lexicons and denotes low-income consumers across various settings, such as rural versus urban poor (Kolk et al., 2014). Nevertheless, most, if not all, of these studies view low-income consumers as separate from the rest of social strata, designing marketing solutions for them alone (London et al., 2014) and barely looking at their connections to other societal strata.

Latterly, there has been a growing awareness of an expanding middle class in emerging markets (EMs) (Chikweche and Fletcher, 2014; Kandogan and Johnson, 2016; Kravets and Sandikci, 2014; Petzer and De Meyer, 2013). Again, nascent focus has viewed the group as a class separate to others, set apart by a newly acquired socio-economic status. The group's potential consumption is vaunted as the growth driver for many global multinationals (Meyer and Peng, 2016). Naturally, to have an emergent middle class, some individuals must have risen out of poverty, implying varying degrees of social mobility. While the mobility itself is acknowledged (Chikweche and Fletcher, 2014; Kravets and Sandikci, 2014), the impact of this on social class interrelation and consumer behavior less so. When the two classes are viewed together, the consumption activity of the wealthier is debated as a source of employment for the impoverished (Neven et al., 2009), or how they impact each other's aspirations (Chipp et al., 2011).

The first contribution this paper makes is to posit that close ties between the emerging middle class and the BoP exist, which manifests in economic support across the pyramid. Therefore, a perspective is advanced through the income pyramid. Longstanding research is brought into social networks and embeddedness (Laud et al., 2015) to understand African consumers. Embeddedness demonstrates how resources are mobilized through networks. A neglected form is cultural embeddedness, which dictates social norms towards social ties (Laud et al., 2015). The second contribution this paper makes is to empirically redress how cultural embeddedness, manifested as ubuntu, impacts class strata. African ubuntu or "rules of the game" reinforce the connection to the collective, where social ties reflect strong interpersonal connections and obligations. Hence, ubuntu could function as a means of accessing resources in the manner foreseen by Laud et al. (2015). Ubuntu values a broad kinship group so when some individuals within the extended family rise out of poverty, they do not become autonomous agents - this can be recognized elsewhere in the duty of caring for parents (Göransson, 2013). Thus, these people are called upon to support others, potentially increasing their social power while decreasing their disposable income (Magubane, 2017). Therefore, it is highlighted that rapid social mobility would not sever interpersonal ties in African markets, but rather provide leverage for 
the low-income group to access resources now available to successful individuals in their networks. The third contribution this research makes is to underscore the new middle class as boundary spanners between class strata. They are between nuclear and extended families, have past experience and current membership of different income groups, understand both worlds, and could act as an economic bridge for others. While their boundary spanning nature has been acknowledged by economics (Chantarat and Barrett, 2012), marketing (Kravets and Sandikci, 2014) and international business (IB) scholars (Zoogah et al., 2015), these fields treat them as an atomistic group, separate from others. The fourth contribution made is to demonstrate that such a perspective can be used in the development of value propositions in insurance. When presented with the opportunity, the middle-income consumers could have the propensity to take out additional insurance on behalf of low-income ones. Insurance has been notoriously difficult to sell to the poor (Yao, 2013), and generally products are informal and involve micro-insurance. Formal insurers have looked at within group social connections, rather than between groups, when designing products for the poor (see Biener and Eling, 2012 for example). Viewing the market as interdependent opens up possibilities to design products for the middle class to augment the informal support they provide to the low-income groups in their network. There may be latent demand for insurance products that relieve the middle class of this burden and assists them in managing the demands on their income.

The current paper first turns to the literature on low- and middle-income consumers in EMs - that is, African and similar countries - with the aim of contributing to this literature. Then, the literature on social networks is examined. Social ties and networks in Africa, particularly in sub-Saharan Africa, are deeply influenced by the concept of ubuntu and this study demonstrates how this accentuates kinship and group ties, and impels mutual support.

\section{Literature review}

\section{The income pyramid}

Work on consumers in EMs has reignited a focus on consumer income level, class and social mobility. When Prahalad (Prahalad and Hammond, 2002) coined the term BoP, he also called into academic focus the markets in which they resided. Other authors viewed BoP to exist mainly, if not solely, in less affluent regions and countries (Kolk et al., 2014). Africa, while universally accepted as a location of BoP consumers and markets, has been understudied (Kolk et al., 2014), despite its potential contextual differences from other regions (Zoogah et al., 2015). The BoP is viewed as a discrete group 
and their relations to others within the society is more one of reference (see Chipp et al., 2011 for example) than resource.

The BoP in EMs has been treated as distinct from low-income groups elsewhere - a demarcation more of practice than clear elucidation. The differentiation between the two could be attributed to the implications of context: the poor in EMs reside in what are termed "subsistence" (Ingenbleek, 2014; Viswanathan and Venugopal, 2015) or "transition" (Mutlu et al., 2015) marketplaces, with different meso- and macro-level influences (Rivera-Santos et al., 2012; Rivera-Santos and Rufín, 2010). There are fewer overall societal resources, manifested in low financial sector coverage, little to no government social support, uneven infrastructure, and weak formal institutions to protect worker rights (Zoogah et al., 2015). Therefore, African low-income consumers are doubly disadvantaged they have few personal resources and operate within a less resourced market with lower levels of formal institutions and support structures (Meyer and Peng, 2016; Peng et al., 2008).

The terminology change from "subsistence" to "transition" marks a alteration in resource levels due to changes in political, economic and social structures (Mutlu et al., 2015; Zoogah et al., 2015), creating greater social and economic diversity. Hence, marketing in recent years has produced studies on the emerging middle class (Chikweche and Fletcher, 2014; Kravets and Sandikci, 2014; Petzer and De Meyer, 2013). Such research either seeks to describe consumers in the strata (Chikweche and Fletcher, 2014) or understand their motivations and drives (Chipp et al., 2011; Kravets and Sandikci, 2014). Kravets and Sandikci (2014) emphasize that the new middle class is aware of its precarious nature as it exists in politically unstable markets with many fellow citizens residing in poverty. When the middle- and low-income groups are studied in tandem, they are often described as two strata within a market, with an emphasis on their differences rather than their commonalities (see for example Petzer and De Meyer, 2013). Little attention has been given to their interrelation beyond their role as reference groups for each other, where low-income individuals aspire to have middleclass lifestyles (Barki and Parente, 2010) and the new middle-income members seek to demonstrate their new status (Chipp et al., 2011; Kravets and Sandikci, 2014). Nevertheless, other than a reference group, the relations between classes are little explored, even though the implications of "new" and "emerging" middle class convey social mobility and connections between different classes.

Middle- and low-income groups in EMs have two main commonalities. First, both reside in subsistence or transition economies. Hence, the middle class are impacted by overall low or average resources levels that prevail, and they too reside in environs where informal rather than formal networks predominate. Furthermore, the middle class are exposed to governments that are unable to provide much of a social support network for the poor. Second, both groups understand poverty since it 
dominates their societies and, if they are newly middle class, they have first-hand experience of poverty themselves, as documented in early Singaporean upward mobility (Göransson, 2013). In South Africa, the newly middle class are black (Chikweche and Fletcher, 2014; Petzer and De Meyer, 2013), and demonstrate first-hand experience of poverty. The new middle class may have relatives who have not been able to progress economically - as Kravets and Sandikci $(2014$, p. 135) note, "'the rest' ... are left behind". Similarly, in the context under study, a substantial part of the populace is unable to advance (Petzer and De Meyer, 2013), which has been found to be black (Chipp et al., 2012, 2013). Where government support structures are lacking, informal support, such as family are called upon. Therefore, if some family members have become socially mobile, the support burden may disproportionately fall to them. Such support has been documented extensively in the popular press in South Africa under the term "black tax" (Ratlebjane, 2015). Colloquially, black tax refers to financial and other support that black newly mobile individuals use to provide for their extended families (Magubane, 2017; Ratlebjane, 2015).

International Business (IB) scholars would also underscore the support of informal networks, as they place great importance on informal institutions in these markets (Meyer and Peng, 2016; Zoogah et al., 2015). Work in economics has modelled beneficial outcomes for low-income households if they have connections with individuals of higher economic strata (Chantarat and Barrett, 2012). Thus, this study seeks to demonstrate that middle-income individuals whose networks contain closer ties to lowincome individuals will be inclined to provide financial support to them, and these obligations would be stronger among the new middle class than the established middle class. To summarize, "through the pyramid" should be most apparent among the socially mobile, as they have first-hand experience of poverty and have relatives who remain there. The socially mobile in South Africa are black and Caucasians are part of the established middle class (Chikweche and Fletcher, 2014; Petzer and De Meyer, 2013). Caucasians have historically exhibited less communal concern (Burgess et al., 1994; Chipp et al., 2013).

This leads to the first hypothesis:

$H_{1}$ : The new middle class would have a greater propensity to give resources to lower income individuals, as operationalized by willingness to pay insurance cover for low-income connections, than the established middle class.

\section{Social networks, cultural embeddedness and ubuntu}

Social relationships, network theory and social capital in emerging markets have been given great prominence in IB literature (Meyer and Peng, 2016; Peng et al., 2008; Rivera-Santos et al., 2012; 
Salvador et al., 2014). IB literature in Africa has also emphasized relationships, institutions and resource bases (Zoogah et al., 2015). Conversely, marketing studies here on low- and middle-income consumers tend to be descriptive, aimed at practitioners (Kolk et al., 2014), focused at micro levels (individual), and treat the BoP as a distinct stratum that is separate from other strata (Blocker et al., 2013; Ingenbleek, 2014; Varman et al., 2012). There is some acknowledgement that social capital is important in low-income environs, although this is not the predominant focus of that literature (see Ingenbleek's, 2014, review).

\section{Defining social capital}

Social capital theory provides a means to understand the instrumental value of social resources that individuals can utilize to improve their economic standing (Viswanathan et al., 2010). Resources are embedded in social structures and can be accessed through an individual's relationships (Laud et al., 2015). Termed social networks, this is the individualistic approach to social capital that treats it as a personal asset enabling private benefits (Chantarat and Barrett, 2012), placing primacy on the interaction between parties (Arun et al., 2015). The relational approach to social capital asserts that such capital is "a property and a quality of social relationships, not an attribute of individuals or social structures" (Donati and Prandini, 2007a, p. 209). Social relations are important because they create social capital by fostering high levels of obligation, expectation and reciprocity, as well as provide information and generate norms and sanctions (Zontini and Reynolds, 2007). Consequently, social networks function as assets whose worth is dependent on the nature and strength of ties at micro, meso and macro levels - that is, the community, market and state (Arun et al., 2015).

Social networks are predominantly formed among individuals who are already acquainted (Chantarat and Barrett, 2012). Social distance determines benefits, since positive returns depend on relationship type, density and strength (Arun et al., 2015). Embeddedness is key in the functioning of networks, as "who knows whom and how well one knows people in a system" (Laud et al., 2015, p. 520). Three dimensions of embeddedness encompass how groups operate: structural, which is the quantum of an individual's connections; relational, referring to connection quality (strong or weak ties); and cultural, meaning the values, norms, meanings and practices that govern individual interaction within a market (Laud et al., 2015). Laud et al. (2015) highlights the importance of this concept for the access and integration of resources in a service ecosystem, directly linking resources and networks in marketing.

\section{Bonding and bridging networks}

There are two main types of networks: bonding and bridging. Bonding networks are homogeneous groups with common interests, while bridging networks are socially heterogeneous with diverse 
interests (Arun et al., 2015). Bonding capital confines relationships to a group's boundaries, while bridging capital expands to new connections (Prandini, 2014). Bonding networks tend to be closed within one context, possessing a high-connection density and hence strong ties, giving members greater normative control over each other (Donati and Prandini, 2007a; Drouhot, 2017). Bridging capital has weaker connections between members, who operate across multiple contexts that create brokerage opportunities for members to mediate amid groups and provide access to different sets of resources (Donati and Prandini, 2007b); where brokers act as "bridges" (Laud et al., 2015). Ties that span multiple, different and unrelated contexts have been termed "community liberated", and the networks they foster are heterogeneous, broad and diverse, consisting of educated, affluent and mobile individuals (Drouhot, 2017). Low-income individuals who are socially isolated are unable to access bonding or bridging capital and languish in a "poverty trap". These poor individuals need connections to wealthier groups to possess bridging capital to manage a socially mediated exit from poverty (Chantarat and Barrett, 2012). Connections between middle- and low-income groups have thus been found to be enablers of social mobility for low-income members.

Based on this discussion of network type, it would be expected that low-income individuals are more likely to be members of bonding networks and the middle class of bridging ones. Nevertheless, the socially mobile, who transit from low to middle income, could potentially possess both kinds of networks. Structurally, their networks would be large and diverse, and contain bonding and bridging networks. Moreover, given the strong ties of bonding networks, the individuals who become brokers through social mobility, would still feel the strong ties of the bonding network, even as they enter the bridging network. There is the potential for a domino effect - where one member of a bonded network becomes socially mobile and is a potential bridge for other members to access resources previously outside of their network, thus becoming socially mobile themselves. However, economists tend to view social mobility as an outcome rather than a driver of network tie formation, so the circular impact of mobility across the market is yet to be fully explored. Mobility has positively impacted the size (structural embeddedness) and influenced the quality (relational embeddedness) of the ties (Drouhot, 2017), and potentially the ability of other poor individuals to leverage connections and become socially mobile (Chantarat and Barrett, 2012).

The quality of social ties lies in strong ones. Often, such strength comes from family ties in bonding groups. Families remain building blocks of social capital, which is recognized in literature as the importance of interpersonal relationships to develop trust, reciprocity, social cohesion and a "good society" (Prandini, 2014). Family capital, which encompasses family relationships within a communal network, is rarely included in sociological studies, since it is viewed as private (Donati and Prandini, 
2007a). Family capital is often thought of as potentially negative as they transmit inequalities from one generation to another (Donati and Prandini, 2007b). This assumes that all family members remain in poverty and none become bridges for other members. Prandini (2014) documents the positive influences of family capital in broader economic and social outcomes. He separates social capital arising from the family who resides together, which is termed specific family social capital; and family members not resident but still in contact, that is kindred social capital. Africans tend to emphasize the extended family (Zoogah et al., 2015), hence this study is interested in both forms.

Therefore, the second hypothesis is that the strength of social ties plays a strong role in the support provided. The middle class will provide more help to those closer in social distance and with strong ties (that is a family member) than those with weak relations.

$\mathrm{H}_{2}$ : Decreased social distance, hence stronger social ties, realize greater expenditure on their lowincome connections.

\section{Cultural embeddedness and ubuntu}

While structural (network size) and relational (quality) embeddedness have been extensively researched and explain types of social networks, the third and most neglected type of embeddedness - cultural embeddedness - deserves attention since it is context based. Cultural embeddedness explains the norms, values, behaviors and practices governing market and citizen interaction (Laud et al., 2015). If the cultural norms support and value others, this should strengthen network ties for bonding and bridging networks, and increase the felt obligations for members who span both. This differs from the western "community liberated" model, where mobile, affluent and well-educated individuals have geographically diverse networks and weak local community ties (Drouhot, 2017). Hence, the African middle class could remain community obligated despite their mobility and affluence. After all, Africa has the longstanding cultural operating principle of ubuntu.

Relationships between people are fundamental in ubuntu, which asserts that "I am because you are and you are because we are". In Xhosa, this is umuntu ngumuntu ngabantu; in Pedi, it is motho ke motho ka bangwe, meaning a man is a man through others; and in Zulu, this is umuntu ngumuntu ngabanye, which translates to a person depends on others to be a person (Corder, 2001). Ubuntu has been viewed as a deeply held personal value (Corder, 2001; Letseka, 2012), a moral theory (Letseka, 2012), and as a "pattern of behaviors that helps integrate members of a society into strong, cohesive in-groups" (Zoogah et al., 2015, p. 15). Group members share an identity, resources and support, show caring, respect and compassion for each other, and receive unquestioning loyalty in return, which 
creates networks of social obligations to and relationships with communities and extended families (Letseka, 2012; Zoogah et al., 2015). Ubuntu has been demonstrated to be closely related to social capital and both have found to have positive social and economic outcomes (Migheli, 2017). Ubuntu builds social networks and calls on both "because of the empathy he feels, the individual will necessarily behave sympathetically when taking his choices" (Migheli, 2017, p. 1217). Therefore, caring for others is a social imperative and resides at the heart of African culture.

Ubuntu as a concept is contested. There are questions regarding its continued existence, multiple interpretations, alignment to other similar but global concepts, and the often contradictory nature of its research (West, 2014). It is not certain that ubuntu persists, as culture is not static but strongly related to the ecological environment. Increased income and mobility is historically associated with declining collectivism and growing individualism (Chiou, 2001; Triandis, 1995, 2001), which is evidenced in South African research (Chipp et al., 2013). Ubuntu itself is strongly associated with notions of mutual dependency and the community's necessity for survival (Migheli, 2017). Thus, the impact of ubuntu could depend on notions of shared fate, most visibly apparent across rural populations (West, 2014).

This leads to the final two hypotheses:

$\mathrm{H}_{3}$ : Heightened awareness of community should increase the insurance premium allocated to others.

$\mathrm{H}_{4}$ : Heightened awareness of community welfare should reinforce reduced social distance and increase the insurance premium allocated to others.

\section{Method}

\section{Context of financial services}

An insurance product was chosen for this experiment as it represents financial support. Moreover, literature on remittances and insurance is proof of the influential role social networks play in providing financial support to the poor. As a first example, migrant workers dispatch money to their families in the form of remittances, often termed household income from abroad (Yang, 2011). Therefore, there is a financial realization of the social asset across nations. Internal migration and remittance could also occur as a consequence of local inequality between urban/rural and individual/extended families, although this phenomenon has been understudied. One model that is understood is the role of remittances as informal insurance between family members (Carling, 2008). 
Consequently, the second example of the power of social networks can be found in the insurance industry in Africa. Unlike remittances, however, informal insurance products tend to focus on the bonding networks of low-income groups. Economists have termed this "natural insurance" and have characterized two types: self-insurance and mutual insurance. Mutual insurance is the informal support to kinship groups in times of disaster and it has been termed the "resource augmentation effect" (Takasaki, 2011). Informal insurance groups, which are more structured with rules of operation and membership procedures - such as the nujè mèji gbê (happiness-unhappiness funds) in Benin or some stokvels in South Africa - rely on social ties, often of kinship or close geographies (LemayBoucher, 2012). Considering these findings, formal insurers have focused on designing products aimed at the low-income groups, which mimic developed world products or existing informal arrangements within the low-income class (Biener and Eling, 2012; Churchill, 2007). As a result, none have designed products aimed at the middle income, who are often called on to support them.

\section{Factorial design}

The study used an experimental vignette methodology in the form of a between-subjects factorial design (Aguinis and Bradley, 2014). The vignette described an addendum to an insurance product aimed at the middle class, offering to cover lower income individuals in their network for an additional fee. Six different vignettes were employed, since a two-by-three factorial design was used. The current factorial design paired each level of every factor with each level of every other factor; and each respondent only saw one type, making it a between-subjects design (Aguinis and Bradley, 2014). The first factor, social distance, had three levels: a community care scheme, a domestic worker, or an extended family member, and was operationalized as:

"Your insurance company is starting to offer you the opportunity to extend your policy to cover the home and contents of a low-income household, assuming you currently pay R500 per month. How much would you be willing to add to your monthly premium to extend your cover for (a family member's/domestic employee's/ community member's) home?"

The second factor, which had two levels, was termed "ubuntu". It aimed to invoke a shared sense of community and was operationalized as follows:

"Levels of poverty are extremely high in South Africa. People fortune enough to have the security of an insurance policy are the minority. A small amount of you can assist in dramatically improving the security and living conditions of other family/friends of your communities." After the scenario was presented, the respondent was asked to indicate hypothetically how much he/she would be prepared to add to their ZAR500 per month insurance policy. 
A list of email addresses was purchased from a reputable South African list provider, enabling each of the scenarios to be randomly sent to consumers who earned a household income in excess of ZAR10 000 per month, had short-term insurance, and were able to access the internet.

\section{Data analysis}

Ordinal logistic regression (OLR) was used to predict how much (ZAR0, ZAR50, ZAR100, ZAR100 or more) individuals were willing to add to a theoretical ZAR500 premium, based on ubuntu (ubuntu present or ubuntu absent), ethnicity (black or Caucasian), and social distance (family, domestic worker, and community care scheme).

OLR allowed for an understanding of ubuntu, ethnicity, social distance, and/or interaction between ubuntu and social distance, and had a statistically significant effect on the willingness to add to a current theoretical premium. OLR was conducted in IBM ${ }^{\circ}$ SPSS version 25 , using the polytomous universal model and generalized linear model procedures (Hosmer et al., 2013; Long and Freese, 2006). To ensure that OLR produced valid results, the absence of multicollinearity was tested, as well as to ensure proportional odds (Williams, 2016).

\section{Results}

There were 389 respondents who met the income and product use criteria. Ninety-five percent of these participants were over the age of $30,66 \%$ were male, and $49 \%$ earned in the top bracket of over ZAR50 000 per month, which was US\$5 549.78 (US\$184 a day) at the time of the study. Middle income has had various definitions in literature, but when viewing qualification on income terms, respondents need to be in the second to fourth quintile of the income distribution or have an annual income above US\$3 900 in purchasing power parity terms (Chikweche and Fletcher, 2014). Therefore, the respondents qualify as being middle income. Just over half of the participants (53.4\%) reported that they financially supported family members who did not live with them. Employment of a domestic worker was high at $91 \%$, and $44.5 \%$ of these had over five years' tenure. 


\begin{tabular}{|c|c|c|c|c|c|c|}
\hline Parameters & Estimates & $\begin{array}{l}\text { Wald } \chi^{2} \\
\text { (df) }\end{array}$ & $\begin{array}{l}\text { p-value } \\
\text { (sig.) }\end{array}$ & $\begin{array}{c}\operatorname{Exp}(b) \\
\text { OR }\end{array}$ & $\begin{array}{l}95 \% \mathrm{Cl} \\
\text { Lower }\end{array}$ & $\begin{array}{l}95 \% \mathrm{Cl} \\
\text { Upper }\end{array}$ \\
\hline \multicolumn{7}{|l|}{ Ethnicity } \\
\hline Black-Caucasian & 1.158 & $15.028(1)$ & 0.000 & 3.158 & 1.766 & 5.648 \\
\hline \multicolumn{7}{|l|}{ Hypothesis 1: Supported } \\
\hline \multicolumn{7}{|l|}{ Social Distance } \\
\hline $\begin{array}{l}\text { Domestic worker - } \\
\text { Community }\end{array}$ & 0.687 & $8.687(1)$ & 0.003 & 1.988 & 1.259 & 3.138 \\
\hline $\begin{array}{l}\text { Family member - } \\
\text { Community }\end{array}$ & 1.533 & $37.006(1)$ & 0.000 & 4.634 & 2.827 & 7.595 \\
\hline $\begin{array}{l}\text { Family member - } \\
\text { domestic worker }\end{array}$ & 0.216 & $37.006(1)$ & 0.000 & 1.533 & 0.132 & 0.354 \\
\hline \multicolumn{7}{|l|}{ Hypothesis 2: Supported } \\
\hline \multicolumn{7}{|l|}{ Ubuntu } \\
\hline No Ubuntu-Lens & 0.581 & $9.020(1)$ & 0.003 & 1.789 & 1.224 & 2.614 \\
\hline \multicolumn{7}{|c|}{ Hypothesis 3: Not Supported } \\
\hline \multicolumn{7}{|l|}{ Interaction } \\
\hline Family*No Ubuntu & 2.676 & $55.390(1)$ & 0.000 & 14.530 & 7.181 & 29.399 \\
\hline Family*Ubuntu & 0.497 & $2.508(1)$ & 0.113 & 1.644 & 0.889 & 3.042 \\
\hline Employees*No Ubuntu & 0.743 & $5.119(1)$ & 0.024 & 2.101 & 1.104 & 3.998 \\
\hline Employees*Ubuntu & 0.663 & $4.879(1)$ & 0.027 & 1.941 & 1.078 & 3.498 \\
\hline Community*No Ubuntu & -0.073 & $0.048(1)$ & 0.826 & 0.930 & 0.485 & 1.781 \\
\hline Community*Ubuntu & 2.749 & $54.320(1)$ & 0.000 & 15.629 & 7.524 & 32.466 \\
\hline \multicolumn{7}{|c|}{ Hypothesis 4: Partially Supported } \\
\hline \multicolumn{7}{|l|}{ Model } \\
\hline (-2) Log Likelihood (sig.) & $\begin{array}{l}142.105 \\
(0.001) \\
\end{array}$ & -- & 0.001 & -- & -- & -- \\
\hline $\begin{array}{l}\text { Pearson Goodness of fit } \\
\text { Chi-square (sig.) }\end{array}$ & $\begin{array}{l}68.882 \\
(0.003)\end{array}$ & -- & 0.003 & -- & -- & -- \\
\hline Cox \& Snell Pseudo $\mathrm{R}^{2}$ & 0.150 & -- & -- & - & -- & -- \\
\hline Nagelkerke Pseudo $\mathrm{R}^{2}$ & 0.158 & -- & -- & -- & -- & -- \\
\hline
\end{tabular}

Results from the variance inflation factor were 1.004, 1.003, and 1.006 for social distance, ubuntu and ethnicity, respectively. Furthermore, the assumption of proportional odds was met, as assessed by a full likelihood ratio test comparing the fit of the proportional odds location model with varying location parameters (test for parallel lines, using the logit link function), $\chi^{2}{ }_{(12)}=32.495, p=0,001$. The final model significantly predicted willingness to add a theoretical premium over and above the interceptonly model, $\chi^{2}(4)=59,471, p<0.00$.

Hypothesis 1: New middle class versus established middle class, viewed in terms of ethnicity.

Ethnicity had a significant effect on the prediction of whether individuals would pay a premium (Wald $\chi^{2}{ }_{(1)}=15.028, p=0.000$ ), where blacks were 3.158 times more likely to pay a premium than Caucasians. 


\section{Hypothesis 2: Social distance}

Social distance had a significant effect on the prediction of whether individuals would pay a premium (Wald $\chi^{2}(2)=37,153, p=0.000$ ). Results from Table 1 indicate that the odds of paying a premium for a domestic worker were 1.988 times more likely than paying a premium for a community care scheme, while it was 4.634 times more likely to pay a premium for a family member in comparison to a community care scheme. Furthermore, the odds of paying a premium for a family member were 1.533 times more likely than paying a premium for a domestic worker. These results support the notion that decreased social distance, with family being the closest, followed by domestic worker and then community, would extract an additional premium payment.

Hypothesis 3: Ubuntu

Ubuntu had a statistically significant effect on the prediction of whether individuals would pay a premium (Wald $\chi^{2}{ }_{(1)}=9.020, p=0.003$ ). However, the results were not in the predicted direction, as the No Ubuntu Frame condition was 1.789 times more likely to pay a premium (see Table 1). Hence, there is no support for an awareness of community being a driver of willingness to pay an additional premium.

Hypothesis 4: Interaction (ubuntu*Social distance)

The interaction between ubuntu and social distance had a significant effect on the prediction of whether individuals would pay a premium (Wald $\chi^{2}{ }_{(2)}=27.327, p=0.000$ ). Individuals without a frame were 14.530 times more likely to pay a premium, $p=0.000$ for family, in contrast to the ubuntu condition of 1.644 times more likely (although $p=0.113$ ). Similarly, the No Frame Condition was 2.101 times more likely to result in a premium payment for domestic workers $(p=0.024)$ against the ubuntu frame (1.941 times more likely to pay a premium, $p=0,027)$. Finally, individuals without a frame were 0.930 times more likely to pay a premium for a community care scheme (however, $p=0.826$ ), in comparison to individuals with a frame, who were 15.629 times more likely to pay a premium for a community care scheme $(p=0.000)$. Consequently, the only instance where the ubuntu frame was effective in increasing premiums was for the most socially distant who had no personal ties.

\section{Discussion}

This research paper found that the new middle class were willing, across all conditions, to add less advantaged others to their insurance premiums. Such a finding reinforces that emerging markets are 
made up of interconnected individuals who support each other in times of loss (Lemay-Boucher, 2012), and extends this to demonstrate that these people span different middle- and low-income levels. Nevertheless, the effect was most pronounced for black respondents (3.158 times more likely to pay than Caucasians), thus stronger ties appear to exist for the newly middle class as they span both bonding and bridging networks. This study has contributed to the consumer behavior and marketing literature by demonstrating that the pyramid in Africa is not a layer cake of unconnected strata, but a web of relationships that function as assets and realize economic gains and support for the less welloff. Such a conceptualization can be used to build products and services for the poor, but is targeted at the middle class, as seen in the insurance example. Service provision for the poor via other groups could solve social issues through innovations (Varadarajan and Kaul, 2018). Such an approach could lead to profitable product development and social welfare, as was Prahalad and Hammond's (2002) original aim.

There are possible implications for developed markets: it is the market structure, namely lack of formal and state social support that increases the pressure on informal social support structures (Zoogah et al., 2015). State support has been positively linked to decreased social inequality, and its lack is linked to rising inequality, often with a racial lens (Saltkjel and Malmberg-Heimonen, 2017). Therefore, products and services that bolster informal support structures, which will be increasingly called upon as state provision falters, could be applied more widely than just in emerging markets. Research on the "sandwich generation" - that is, individuals who support children and aging parents - has recently turned to financial support for relatives (Bogan, 2015), as opposed to its traditional focus of psychological support (O'Sullivan, 2015).

Social distance was found to be the greatest influence of support in terms of adding to a premium of an insurance policy. Many previous studies have viewed African societies, particularly South Africa, in general as having polarized homogeneous groups of low-income individuals and elites (Letseka, 2012), similarly to South America (Torche, 2014). The growing social mobility in African markets has started to change this and connected low-income, localized homogeneous, bonding groups to more affluent, heterogeneous and bridging groups. Hence, many middle-class consumers in the market remain willing to give to the poor, who are people in their own families, personal employ and neighboring communities. Nevertheless, the tenets of social networks are still in place - they will pay more for those closest to them and less for those less associated with them. In doing so, this paper empirically demonstrates the conceptual work of Laud et al. (2015) that networks are sites of resource access and integration. This payment phenomenon is well-documented in popular press and termed black tax or ubuntu tax, where extended kinship groups must be supported by the newly middle class. Since the 
payment is for someone else, these results could implicate literature on vicarious consumption, which has looked at moral reasons for childcare (Brusdal and Frønes, 2013). In doing so, this research also extends the often neglected domestic remittances literature in sub-Saharan Africa (Stephens et al., 2014), by showing that this operates across class boundaries and extends beyond family members. Moreover, insurance could consider within group coverage, or mutual insurance, to span income groups and design products accordingly.

Ubuntu entails a caring and social obligation to the broader community and society (Letseka, 2012). However, the operationalization of this paper, which emphasized social need for the broader community as a motivating factor to pay, found contradictory results. Measuring and operationalizing a concept as complex as ubuntu is difficult, since scholars note that the term cannot be properly translated or even fully conveyed in English, and it incorporates a sense of community and kinship with the living and ancestors (West, 2014). Given the deep nature of ubuntu, the concept could be present simply by mention of the word "family", as scholars have argued that there may be differences between western and African notions of "family" (West, 2014). However, at a non-personal level, ubuntu elicited higher payments to individuals outside of the ostensible network. Such a finding is in line with authors who place notions of a shared fate (Migheli, 2017; West, 2014) at the heart of the concept - family or employees require no ubuntu lens for a shared fate to be apparent. Abstract, impersonal communities do. Therefore, not surprisingly, higher kinship appeal worked under this condition alone.

The current study is the first step towards understanding the complex networks that exist between income groups in African markets. The research focused on a potential insurance product, which is an outcome of hypothesized network relations. Future studies could explore the deeper levels of the relations between the socially mobile, their cultural embeddedness, and how they support social ties, both strong and weak. A notion of a consumer being in transition or between styles of life - the traditional and the modern; the local and the global - is worth exploring and is in contrast to the binary was-low-income/is-now-middle-income approach evidenced in much of the literature (Sharma et al., 2018; Zoogah et al., 2015).

Research into the social burdens on the middle class could possibly reveal that social obligations give them lower than expected disposable income and reduces their ability to progress. The current study's respondents were predominantly above the age of 30 and half had high incomes, and hence were able to afford policy premiums. The burden on younger graduates, who may have to pay for both siblings and extended family (Ratlebjane, 2015), could be felt very differently. The support burden in the current study was economic and one way; it could be more than economic and work both ways. 
Communities may have pooled resources to educate some of their members so they could become socially mobile. Other forms of support could be social entrepreneurship, where the emerging middle class may feel compelled to start social businesses to "give back" to their bonding community that helped them become successful. Similarly, of potential importance is how long an individual has been middle income - their relations to others may change over time, depending on whether they are firstor second-generation middle class. Consequently, it is believed that a "through the pyramid" approach to African markets offers a separate and rich stream of research to the atomistic and banded "middle" and "low" income view. 


\section{References}

Aguinis, H. and Bradley, K.J. (2014), "Best practice recommendations for designing and implementing experimental vignette methodology studies", Organizational Research Methods, Vol. 17 No. 4, pp. 351-371.

Arun, S., Annim, S. and Arun, T. (2015), "Do all networks 'work'? The mediating role of social networks on consumption expenditure in India", Sociology, Vol. 50 No. 3, pp. 522-541.

Barki, E. and Parente, J. (2010), "Consumer behaviour of the base of the pyramid market in Brazil", Greener Management International, No. 56, pp. 11-23.

Biener, C. and Eling, M. (2012), "Insurability in microinsurance markets: an analysis of problems and potential solutions", The Geneva Papers on Risk and Insurance: Issues and Practice, Vol. 37 No. 1, pp. 77-107.

Blocker, C.P., Ruth, J.A., Sridharan, S., Beckwith, C., Ekici, A., Goudie-Hutton, M., Rosa, J.A., et al. (2013), "Understanding poverty and promoting poverty alleviation through transformative consumer research", Journal of Business Research, Vol. 66 No. 8, pp. 1195-1202.

Bogan, V.L. (2015), "Household asset allocation, offspring education, and the sandwich generation", American Economic Review, Vol. 105 No. 5, pp. 611-615.

Brusdal, R. and Frønes, I. (2013), "The purchase of moral positions: an essay on the markets of concerned parenting", International Journal of Consumer Studies, Vol. 37 No. 2, pp. 159-164.

Burgess, S.M., Schwartz, S. and Blackwell, R.D. (1994), "Do values share universal content and structure? A South African test", South African Journal of Psychology, Vol. 21 No. 1, pp. 1-12, available at: https://doi.org/10.1177/008124639402400101.

Carling, J. (2008), "The determinants of migrant remittances", Oxford Review of Economic Policy, Vol. 24 No. 3, pp. 582-599.

Chantarat, S. and Barrett, C.B. (2012), "Social network capital, economic mobility and poverty traps", The Journal of Economic Inequality, Vol. 10 No. 3, pp. 299-342.

Chikweche, T. and Fletcher, R. (2014), "'Rise of the middle of the pyramid in Africa': theoretical and practical realities for understanding middle class consumer purchase decision making", Journal of Consumer Marketing, Vol. 31 No. 1, pp. 27-38.

Chiou, J.-S. (2001), "Horizontal and vertical individualism and collectivism among college students in the United States, Taiwan, and Argentina", The Journal of Social Psychology, Vol. 141 No. 5, pp. 667-678.

Chipp, K., Corder, C. and Kapelianis, D. (2012), "Where practice meets theory: defining and reviewing the bottom of the pyramid for South African marketers", Management Dynamics, Vol. 21 No. 1, pp. 18-29.

Chipp, K., Corder, C. and Kapelianis, D. (2013), "The role of collectivism in defining the South African bottom of the pyramid", Management Dynamics, Vol. 22 No. 1, pp. 2-13.

Chipp, K., Kleyn, N. and Manzi, T. (2011), "Catch up and keep up: relative deprivation and conspicuous consumption in an emerging market", Journal of International Consumer Marketing, Vol. 23 No. 2, pp. 117-134.

Churchill, C. (2007), "Insuring the low-income market: challenges and solutions for commercial insurers", The Geneva Papers on Risk and Insurance: Issues and Practice, Vol. 32 No. 3, pp. 401412. 
Corder, C.K. (2001), "The identification of a multi-ethnic South African typology", Unpublished doctoral dissertation, University of Pretoria, Pretoria.

Donati, P. and Prandini, R. (2007a), "The family in the light of a new relational theory of primary, secondary and generalized social capital", International Review of Sociology, Routledge, Vol. 17 No. 2, pp. 209-223.

Donati, P. and Prandini, R. (2007b), "Family and social capital: European contributions", International Review of Sociology, Vol. 17 No. 2, pp. 205-208.

Drouhot, L.G. (2017), “Reconsidering 'community liberated': how class and the national context shape personal support networks", Social Networks, Vol. 48, pp. 57-77.

Göransson, K. (2013), "Manoeuvring the middle ground: social mobility and the renegotiation of gender and family obligations among Chinese Singaporeans", Norwegian Journal of Geography, Vol. 67 No. 4, pp. 249-258.

Hosmer, D.W., Lemeshow, S. and Sturdivant, R.X. (2013), Applied Logistic Regression, 3rd ed., Wiley, New Jersey, NJ.

Ingenbleek, P.T.M. (2014), “From subsistence marketplaces up, from general macromarketing theories down: bringing marketing's contribution to development into the theoretical midrange", Journal of Macromarketing, Vol. 34 No. 2, pp. 199-212.

Kandogan, Y. and Johnson, S.D. (2016), "Role of economic and political freedom in the emergence of global middle class", International Business Review, Vol. 25 No. 3, pp. 711-725.

Khoza, R. (1994), Ubuntu Botho African Humanism: A Discussion Paper on Ubuntu as a Philosophy of Life and its Potential Application, Ekhaya, Soweto.

Kolk, A., Rivera-Santos, M. and Rufín, C. (2014), "Reviewing a decade of research on the 'base/bottom of the pyramid' (BOP) concept", Business \& Society, Vol. 53 No. 3, pp. 338-377.

Kravets, O. and Sandikci, O. (2014), "Competently ordinary: new middle class consumers in the emerging markets", Journal of Marketing, Vol. 78 No. 4, pp. 125-140.

Laud, G., Karpen, I.O., Mulye, R. and Rahman, K. (2015), "The role of embeddedness for resource integration: complementing S-D logic research through a social capital perspective", Marketing Theory, Vol. 15 No. 4, pp. 509-543.

Lemay-Boucher, P. (2012), "Insurance for the poor: the case of informal insurance groups in Benin", The Journal of Development Studies, Vol. 48 No. 9, pp. 1258-1273.

Letseka, M. (2012), "In defence of ubuntu", Studies in Philosophy and Education, Vol. 31 No. 1, pp. 47-60.

London, T., Esper, H., Grogan-Kaylor, A. and Kistruck, G.M. (2014), “Connecting poverty to purchase in informal markets", Strategic Entrepreneurship Journal, Vol. 8 No. 1, pp. 37-55.

Long, J.S. and Freese, J. (2006), Regression Models for Categorical Dependent Variables Using Stata, Sage, Thousand Oaks, CA.

Magubane, N. (2017), "Black tax : the emerging middle class reality", Unpublished masters thesis, Gordon Institute of Business Science, University of Pretoria, available at:

https://repository.up.ac.za/bitstream/handle/2263/59861/Magubane_Black_2017.pdf?sequen $\mathrm{ce}=1$ (accessed 26 February 2018).

Meyer, K.E. and Peng, M.W. (2016), "Theoretical foundations of emerging economy business research", Journal of International Business Studies, Vol. 47 No. 1, pp. 3-22. 
Migheli, M. (2017), "Ubuntu and social capital: a strong relationship and a possible instrument of socio-economic development", Cambridge Journal of Economics, Vol. 41 No. 4, pp. 1213-1235.

Mutlu, C.C., Zhan, W., Peng, M.W. and Lin, Z. (John). (2015), "Competing in (and out of) transition economies", Asia Pacific Journal of Management, Vol. 32 No. 3, pp. 571-596.

Neven, D., Odera, M.M., Reardon, T. and Wang, H. (2009), "Kenyan supermarkets, emerging middleclass horticultural farmers, and employment impacts on the rural poor", World Development, Vol. 37 No. 11, pp. 1802-1811.

O'Sullivan, A. (2015), "Pulled from all sides: the sandwich generation at work.", Work, Vol. 50 No. 3, pp. 491-494.

Peng, M.W., Wang, D.Y.L. and Jiang, Y. (2008), "An institution-based view of international business strategy: a focus on emerging economies", Journal of International Business Studies, Vol. 39 No. 5, pp. 920-936.

Petzer, D.J. and De Meyer, C.F. (2013), "Trials and tribulations: marketing in modern South Africa", European Business Review, Vol. 25 No. 4, pp. 382-390.

Prahalad, C.K. and Hammond, A. (2002), "Serving the world's poor, profitably", Harvard Business Review, Vol. 80 No. 9, pp. 48-57.

Prandini, R. (2014), "Family relations as social capital”, Journal of Comparative Family Studies, Vol. 45 No.2, pp. 221-234.

Ratlebjane, M. (2015), “How 'black tax' cripples our youth's aspirations”, Mail \& Guardian, 30 October, available at: https://mg.co.za/article/2015-10-29-how-black-tax-cripples-our-youthsaspirations (accessed $x x$ xxxxxx $x x x x$ ).

Rivera-Santos, M. and Rufín, C. (2010), "Global village vs. small town: understanding networks at the base of the pyramid", International Business Review, Vol. 19 No. 2, pp. 126-139.

Rivera-Santos, M., Rufín, C. and Kolk, A. (2012), "Bridging the institutional divide: partnerships in subsistence markets", Journal of Business Research, Vol. 65 No. 12, pp. 1721-1727.

Saltkjel, T. and Malmberg-Heimonen, I. (2017), "Welfare generosity in Europe: a multi-level study of material deprivation and income poverty among disadvantaged groups", Social Policy \& Administration, Vol. 51 No. 7, pp. 1287-1310.

Salvador, E., Pinot de Villechenon, F. and López Rizzo, H. (2014), "European SMEs and the Brazilian market", European Business Review, Vol. 26 No. 4, pp. 368-388.

Sharma, P., Luk, S.T.K., Cardinali, S. and Ogasavara, M.H. (2018), "Challenges and opportunities for marketers in the emerging markets", Journal of Business Research, Vol. 86, pp. 210-216, available at: https://doi.org/10.1016/j.jbusres.2018.01.065.

Stephens, N.M., Markus, H.R. and Phillips, L.T. (2014), "Social class culture cycles: how three gateway contexts shape selves and fuel inequality", Annual Review of Psychology, Vol. 65 No. 1, pp. 611634.

Takasaki, Y. (2011), "Do the commons help augment mutual insurance among the poor?", World Development, Vol. 39 No. 3, pp. 429-438.

Torche, F. (2014), "Intergenerational mobility and inequality: the Latin American case", Annual Review of Sociology, Vol. 40 No. 1, pp. 619-642.

Triandis, H. (1995), Individualism and Collectivism, Westview Press, Boulder, CO.

Triandis, H.C. (2001), "Individualism-collectivism and personality", Journal of Personality, Vol. 69 No. 
6, pp. 907-924.

Varadarajan, R. and Kaul, R. (2018), "Doing well by doing good innovations: alleviation of social problems in emerging markets through corporate social innovations", Journal of Business Research, Vol. 86, pp. 225-233.

Varman, R., Skålén, P. and Belk, R.W. (2012), "Conflicts at the bottom of the pyramid: profitability, poverty alleviation, and neoliberal governmentality", Journal of Public Policy \& Marketing, Vol. 31 No. 1, pp. 19-35.

Viswanathan, M., Rosa, J.A. and Ruth, J.A. (2010), "Exchanges in marketing systems: the case of subsistence consumer-merchants in Chennai, India", Journal of Marketing, Vol. 74 No. 3, pp. 117.

Viswanathan, M. and Venugopal, S. (2015), "Subsistence marketplaces: looking back, looking forward", Journal of Public Policy \& Marketing, Vol. 34 No. 2, pp. 228-234.

West, A. (2014), "Ubuntu and business ethics: problems, perspectives and prospects", Journal of Business Ethics, Vol. 121 No. 1, pp. 47-61.

Williams, R. (2016), "Understanding and interpreting generalized ordered logit models", The Journal of Mathematical Sociology, Vol. 40 No. 1, pp. 7-20.

Yang, D. (2011), “Migrant remittances", Journal of Economic Perspectives, Vol. 25 No. 3, pp. 129-152.

Yao, Y. (2013), "Development and sustainability of emerging health insurance markets: evidence from microinsurance in Pakistan.", The Geneva Papers on Risk and Insurance: Issues and Practice, Vol. 38 No. 1, pp. 160-180.

Zontini, E. and Reynolds, T. (2007), "Ethnicity, families and social capital: caring relationships across Italian and Caribbean transnational families", International Review of Sociology, Vol. 17 No. 2, pp. 257-277.

Zoogah, D.B., Peng, M.W. and Woldu, H. (2015), "Institutions, resources, and organizational effectiveness in Africa", Academy of Management Perspectives, Vol. 29 No. 1, pp. 7-31. 